\title{
Thermal parameters of roofing slates from Czech Republic
}

\author{
Małgorzata Labus ${ }^{1}$ (D) $\cdot$ Krzysztof Labus $^{1} \cdot$ Petr Bujok $^{2}$
}

Received: 27 July 2019 / Accepted: 25 October 2019 / Published online: 9 November 2019

(C) The Author(s) 2019

\begin{abstract}
Thermal performance of building materials is an important parameter from the point of view of energy consumption for heating buildings, which is obviously related to environmental protection standards. Thermal parameters of roofing slates were measured for samples from two different formations in the Czech Republic. These were rocks of lower Carboniferous Culm facies of Moravice Formation and Silesian Unit of Flysch Moravian-Silesian Carpathians. Thermal conductivity and thermal effusivity measurements were performed with use of TCi analyser. Thermal parameters were obtained in parallel and perpendicular direction to the bedding in rocks. Thermal conductivity of the Moravian slates in the direction perpendicular to the bedding ranges from 1.43 to $1.79 \mathrm{~W} \mathrm{~m}^{-1} \mathrm{~K}^{-1}$, while for samples from Carpathian region this parameter ranges from 1.99 to $3.15 \mathrm{~W} \mathrm{~m}^{-1} \mathrm{~K}^{-1}$. High values of thermal conductivity correlate to higher quartz content in the rocks. The measured thermal parameters (conductivity, effusivity, diffusivity) are strongly depending on the direction of measurement. Thermal conductivity of analysed rocks increases along with increase in temperature. The increase in thermal conductivity value is more significant in case of Moravian slates. In practice, the obtained results indicate that the traditional building material, such as roofing slates, shows better insulation properties at lower temperatures, while in conditions of strong sunlight the temperature conductivity increases. In case of roofing slates, which tend to be highly anisotropic, the essential information is the direction of thermal parameters measurement. Slates, due to their specific texture, are characterized by a very high thermal anisotropy coefficient.
\end{abstract}

Keywords Roofing slates $\cdot$ Building material $\cdot$ Thermal conductivity $\cdot$ Diffusivity

\section{Introduction}

Thermal performance of building materials is an important parameter from the point of view of energy consumption for heating buildings, which is obviously related to environmental protection standards. The smaller the thermal conductivity coefficient, the less heat conducts the material, and therefore better isolates against its losses.

The topic of this article is the thermal properties of rocks used as roofing material. At the outset, the difference between the "shale" and "slate" words used here must be clarified. Sometimes these terms are used interchangeably, although from a geological point of view they mean rocks

Małgorzata Labus

malgorzata.labus@polsl.pl

1 Silesian University of Technology, 2 Akademicka St., Gliwice, Poland

2 VSB - Technical University of Ostrava, 17. Listopadu St., 2172 Ostrava-Poruba, Czech Republic of a different origin. Shale is sedimentary rock, lightly compacted into thin, crumbly layers. It may contain high concentrations of quartz, feldspars, pyrites, amorphous silica and clay minerals: illite, kaolinite, chlorite and smectite (montmorillonite). The presence of clay minerals from the smectite group may cause increased absorption of water through the rock. Slate, a metamorphic rock, on the other hand is usually much stronger and does not absorb water. Slate is a microcrystalline metamorphic rock characterized by a highly developed rock cleavage. The common colours of slate are black, grey, purplish and greenish. Composed of quartz and stable sheet silicates (such as muscovite mica), slate has a high durability. Prehistoric tombs built of slate in the French Alps are still in good condition after 2500 years [1]. Slate is commonly used for roofing and paving tiles. Roofing slates (Germ. Dachschiefern, French. ardoises, schistes ardoisičres, Czech štipatelné břridlice) is a technical term, referring to various types of shale or slate used for roofing. In Europe, the traditions of extracting and using slate as roofing materials are very strong [2]. The oldest documented 
examples of shale use come from Roman times; roofing slate was also widely used in the Middle Ages, and in the sixteenth century it was even exported. Currently, there is a revival of extraction and use of roofing slate, especially in Germany and Spain, due to their aesthetic value and durability. In the area of their occurrence, in the Ardennes, the Spanish Messe, the Central Massif, the Thuringian Forest and Moravia, it is still widely used. The history of exploitation and use of roofing slate coming from Western Europe has been very broadly and thoroughly described by Cardenes et al. [2, 3]. This paper will be focused on roofing slates coming from the Czech Republic, with special regard to their thermal properties.

\section{Roofing slates of Czech Republic}

Rocks that can be split into thin plates, suitable as roofing slates, are present in various formations in Czech Republic, as reported by Wagner et al. [4]:

1. Proterozoic phyllites (at Rabštejn and Manètin),

2. Cambrian-Ordovician phyllites in the Jizera-Krkonoše crystalline complex, as well as the deposits in the area Železný Brod,

3. Ordovicialn phyllites of the Phycodens group at Kraslice in the Krušne Hory Mts.,

4. Cambrian-Ordovician phyllites of the eastern part of the Krkonoše Mts.,

5. Culm slates in the Nízky Jeseník Mts. and the Odra Hills of Moravia and Silesia (at Svatoňovice and Novè Těchanovice-Lhotka),

6. Jurassic and Cretaceous slates in the Malé Karpaty Mts.

Currently, only in the Moravian region, slates belonging to Moravice Formation of Mississippian/Carboniferous system are still used to a small extent for roofing. This is the reason that our interest in this paper is focused on this group (No. 5) of slates. The last group (No. 6) is also sampled and examined in our research, for comparative study.

Culm slates (of the Andelskohorska and Moravian formations) occurring in Moravia were extensively used as a roofing material. In 1880, 52 slate mining plants operated in the region of Silesia and Moravia. Exploitation of the slate near Budišov lasted until 1972. In the nearby mining plant in Lhotka (Bridlicovy Dul Lhotka s.r.o.—deep mine) continues production of slate claddings and various roof tile shapes. Thanks to the returning global comeback to the natural building materials; this raw material is widely exported. Currently, in the area of Budišov and Vitkov, there is a tourist "Slate Route" and also the Slate Museum in Budišov upon Budišovka.
In the village of Mokřinky, in the Morawica valley, there are abandoned places of exploitation of tile slates of the Moravian formation. For use as roofing material, diagenetically altered, thick mudstones and claystones, without coarse fractions were the most suitable. The exploitation of slate was initiated here in the mid-19th century by Josef Nittmann in a deep excavation near the road from Zálužne to Mokřinky. The deposit, stretching further to the north, was characterized by high-quality raw material. Around 1890, the "Carl" shaft was deepened to $82 \mathrm{~m}$, widened and connected underground with another, newly opened at that time, the neighbouring mine "Friderike". In the times of the First Czechoslovak Republic, during the period of agricultural reform in the 1920s, part of the property and the mine were confiscated. The mine was bought then by a Czech expert in the field of mining of the slate-Jan Řihák. He continued to exploit the field until the beginning of World War II, when he lost his mine. Soon afterwards, mining was finally completed [5].

The extraction of tile slates on the land belonging to Nové Techanovice started several dozen years later than in Zálužné and continued many years after World War II (extraction in the "Pollak" tunnel was completed in 1971). The slates were mined in underground excavations; in 1941 the shaft "Lhotka" was hollowed out, connecting the tunnel "Lhotka with the surface of the earth. Slate of a very good quality, from steel blue to navy blue, was extracted here.

About half a kilometre north of Lhotka village there is an underground slate mine "Vitkov-Lhotka". One of the reasons for undertaking exploitation in the 1960s was the need to obtain material for the reconstruction of monuments, including The National Theatre in Prague [5]. The shale is extracted from a depth of about $50 \mathrm{~m}$, which guarantees good quality of the raw material. The cutting technology introduced in the mine, without the use of explosives, allows obtaining large blocks of raw material, free of microcracks. The good cleavage of the rocks in deposits permitted production of roofing slate of a thickness of 5-8 $\mathrm{mm}$. Slate Mine Lhotka has been operating since 2006.

\section{Technical requirements for slate as roofing material}

Technical requirements for slate tiles serving as roofing are given in EN 12326-1:2014 "Slate and stone for discontinuous roofing and external cladding" (3 parts) [6]. A relatively unambiguous chemical criterion is the $\mathrm{CaO}$ content; if it exceeds 5\%, slate can not be used as a roofing material. The said standard (EN 12326) does not specify thermal parameters of slate tiles.

Due to the susceptibility of the rock to weathering, the content in the shale rock of iron sulphides is important (not 
standardized by the above-mentioned document). The sulphide (e.g. pyrite) oxidation process causes the formation of rust stains, reducing the aesthetic values of the slate. At the same time, however, the released sulphur ions, reacting with the carbonates contained in the rock, contribute to the gypsum crystallization. This phenomenon has a negative effect on the strength of the rock, due to its disintegration by gypsum, whose volume (as a hydrated mineral) is higher than the starting components $[2,7]$.

Due to the fine-grained structure of the rock, the objective determination of the mineral composition poses some difficulties. Wagner [8], therefore, proposed the use of normative mineral composition, analogously to the CIPW method for igneous rocks.

\section{Thermal parameters}

\section{Thermal conductivity}

One of the basic thermal parameters of rocks is their thermal conductivity ( $\lambda$ or $k$ ), characterizing the ability of the material to conduct heat. It can be defined as the quantity of heat $(Q)$ transmitted through a unit thickness of a material-in a direction normal to a surface of unit area-due to a unit temperature gradient under steady state conditions:

$k=\frac{Q \cdot l}{s \cdot\left(T_{0}-T_{1}\right) \cdot t}$

where $k$-thermal conductivity coefficient $\left(\mathrm{W} \mathrm{m}^{-1} \mathrm{~K}^{-1}\right)$, $Q$ - quantity of heat (J), $l$-thickness of the material-distance between the surfaces of different temperature $T_{0} \mathrm{i} T_{1}$, $\left(T_{0}>T_{1}\right)(\mathrm{m}), t$-time (s), $s$ - $\operatorname{area}\left(\mathrm{m}^{2}\right)$.

Thermal conductivity of rocks depends on their mineral composition, grain size, porosity, size and shape of pores as well as temperature and pressure [9]. Research by many authors, e.g. $[10,11]$, showed that the thermal conductivity of the rocks (mostly igneous) decreases with the temperature increase to approx. $800{ }^{\circ} \mathrm{C}$. In case of other rocks (stratified sedimentary and some metamorphic), the relation is not so obvious. Studies of thermal parameters of rocks are conducted, among others in terms of the possibility of using geological structures to build closed geothermal systems $[12,13]$ and geothermal modelling [14]. Thermal parameters are also determined in relation to rock building materials in the aspect of saving heating energy [15]. In the case of standard tests of thermal conductivity of building materials, the ambient humidity is taken into account. The following sets of reference conditions are used in European literature and practice: average temperature: 10 or $23^{\circ} \mathrm{C}$, and humidity: dry condition or condition corresponding to equilibrium with air with $50 \%$ or $80 \%$ relative humidity.

\section{Thermal diffusivity}

Thermal diffusivity $\alpha\left(\mathrm{mm}^{2} \mathrm{~s}^{-1}\right.$ ) (also known as temperature compensation coefficient) is a specific property of a material characterizing heat conduction under transient heat flux conditions. This value gives information how quickly a material reacts to a change in temperature, and it describes the dynamics of heat dissipation. The relationship between thermal diffusivity and conductivity is as follows:

$\alpha=\frac{k}{\rho \cdot C_{\mathrm{p}}}$

where $k$-thermal conductivity coefficient $\left(\mathrm{W} \mathrm{m}^{-1} \mathrm{~K}^{-1}\right), \rho$ material density $\left(\mathrm{kg} \mathrm{m}^{-3}\right), C_{\mathrm{p}}$ - specific heat $\left(\mathrm{J} \mathrm{kg}^{-1} \mathrm{~K}^{-1}\right)$.

The dependence of thermal diffusivity on effusivity is described by the formula:

$\alpha=\frac{k^{2}}{e^{2}}$

where $k$-thermal conductivity coefficient $\left(\mathrm{W} \mathrm{m}^{-1} \mathrm{~K}^{-1}\right)$, $e$ - thermal effusivity (W s ${ }^{0.5} \mathrm{~m}^{-2} \mathrm{~K}^{-1}$ ),

Thermal effusivity, also known as thermal activity, is a measure of the material's ability to exchange heat with the environment.

\section{Sampling and analytical methods}

Sampling was performed within two formations, mentioned in chapter 2: Moravice Formation and Carpathian unit. The samples were collected from outcrops. In the case of the Lhotka deep mine, the sample was obtained from the raw material stock located on the surface.

The eight samples representing lower Carboniferous Culm facies of Moravice Formation (Fig. 1) are listed in Table 1. Four samples were taken from Silesian Unit of Flysch Carpathians (Moravian-Silesian Carpathians) (Figs. 2, 3). They represent Vendrynĕ, Hradiště and Veřovice Formations (Table 1).

Mineral composition of the samples was determined by XRD analysis on Bruker-AXS D8 Advance powder diffractometer, equipped with LynxEye linear semiconductor detector and SOL-XE energy-dispersive detector. Measurements were performed with the use of $\operatorname{CoK} \alpha$ lamp, voltage $40 \mathrm{kV}$, intensity $40 \mathrm{~mA}$, angle range $2 \Theta: 6^{\circ}-80^{\circ}$, step $0.014^{\circ}$. The BrukerDiffracSuite software was used to measure and process the results. The PDF-2 database, version 2011 (International Center for Diffraction Data, Pennsylvania, USA), was also used for the qualitative assessment. For the semi-quantitative analysis, based on the Rietveld method, the Bruker Topas 4.1 software was used. 


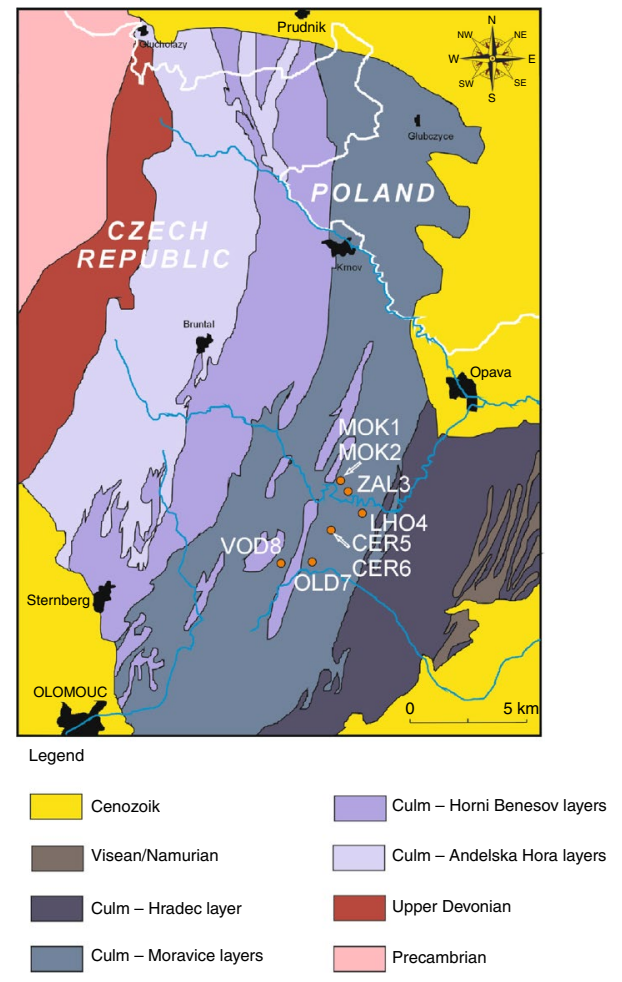

Fig. 1 Geological map and sampling places for Moravice Formation

Table 1 Sampling places and stratigraphic position of the examined rocks

\begin{tabular}{lll}
\hline Sample & Location & Formation \\
\hline MOK1 & Mokřinky (former Anna Mine) & Culm \\
MOK2 & Mokřinky (former Nittmann Mine) & Moravice Formation \\
ZAL3 & Zalužne (Raabove Doly) & $\mathrm{C}_{1}$ \\
LHO4 & Lhotka & \\
CER5 & Čermna (former Žluty Kvet Mine) & \\
CER6 & Čermna (Čermensky Mlyn) & \\
OLD7 & Stare Oldřuvky & \\
VOD8 & Stara Voda & \\
VEG1 & Vendryně & Vendrynĕ Formation \\
& & $\mathrm{J}_{3}$ \\
TRG1 & Třinec & The Cieszyn beds \\
& & Vendrynĕ Formation \\
& & $\mathrm{J}_{\text {K }}$ \\
OSTR1 & Ostravice & Hradiště Formation \\
& & $\mathrm{K}_{1}$ \\
KUN2 & Kunčice pod Ondřejníkem & Veřovice Formation \\
& & $\mathrm{K}_{1}$ \\
\hline
\end{tabular}

Thermal conductivity and thermal effusivity measurements were performed with use of TCi analyser (by C-THERM Technologies Ltd.). Thermal Conductivity Analyser C-Therm employs Modified Transient Plane Source

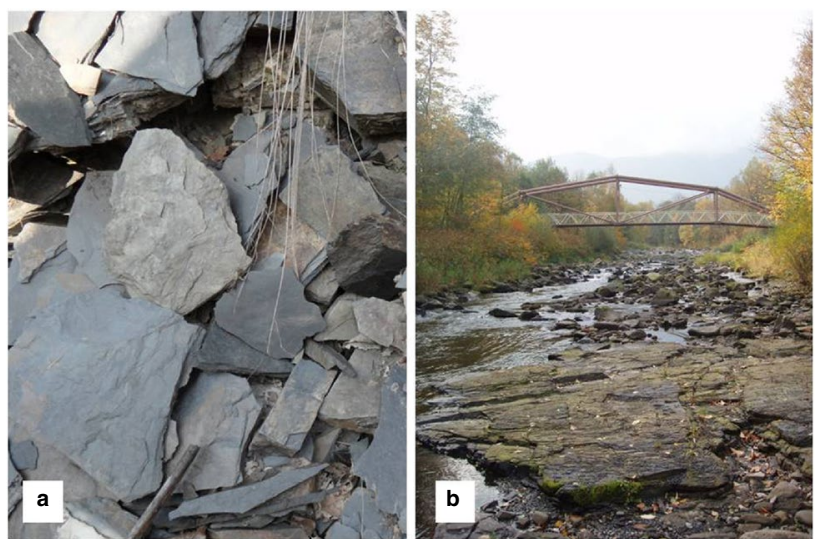

Fig. 2 Outcrops of selected examined rocks: a Čermna - Čermensky Mlyn (sample CER6), b Ostravice (sample OSTR1)

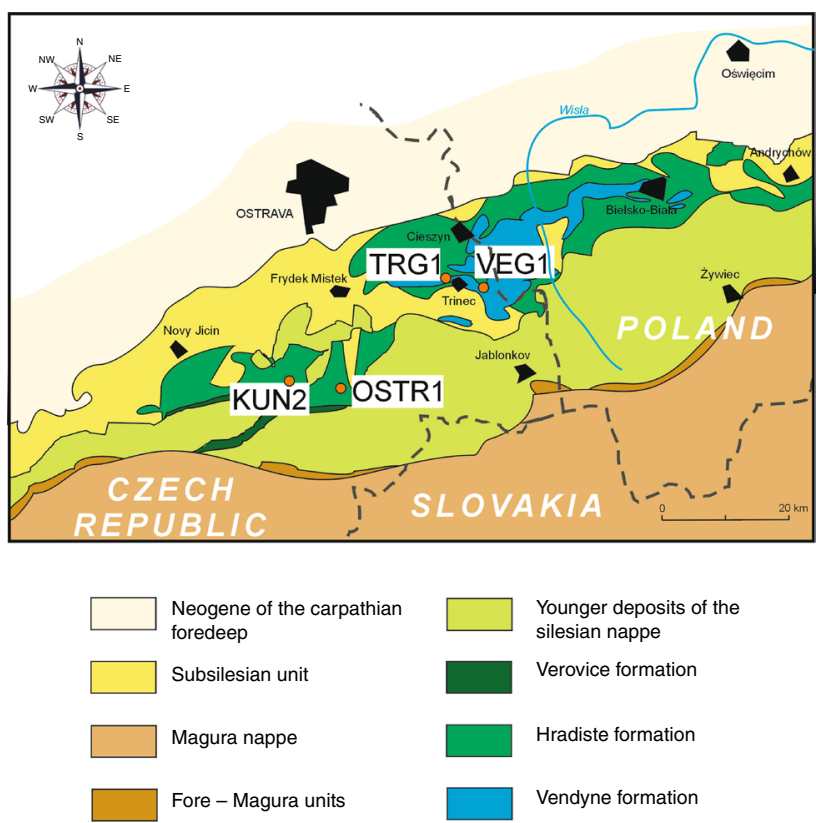

Fig. 3 Geological map and sampling places for Silesian Unit of Flysch Carpathians

(MTPS) technique. The one-sided, interfacial heat reflectance sensor applies a momentary constant heat source to the sample. Measurements consist in recording the voltage change over the source/sensor while its temperature is slightly increased by an electrical current pulse. The pulse is as short as the sensor element can be considered to be in contact with infinite or semi-infinite solid during the measurement. Measurement time is chosen in a way, that the boundaries of the sample do not influence the temperature rise of the element to any measurable extent $[16,17]$. Thermal conductivity and effusivity were measured directly, with the precision within $1 \%$ RSD, and accuracy within $5 \%$ error. 


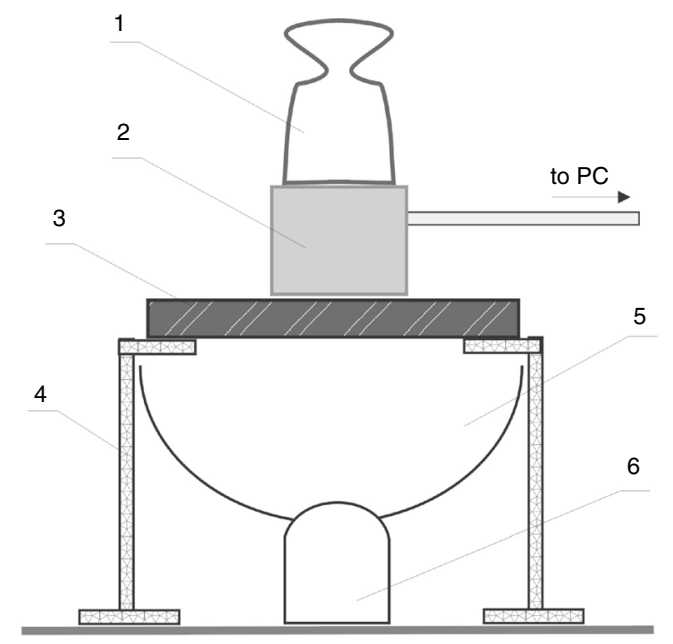

Fig. 4 Stand for measuring thermal parameters in simulated solar conditions

Samples were prepared from the rock, so as to have smooth surfaces of diameter at least $17 \mathrm{~mm}$, adapted to the dimensions of the flat surface of the sensor head. The thickness of the samples was between 20 and $30 \mathrm{~mm}$. Thermal conductivity values were measured in parallel and perpendicular direction to the bedding of rocks. The contact agent (deionized water) was applied between the sensor and the sample, to reduce the thermal resistance to a negligible level. The final result of thermal conductivity and effusivity was obtained from 10 averaged measurement results.

Measurements of thermal parameters of rocks were carried out in several temperature states: at approx. 16, 23, 60 and $80^{\circ} \mathrm{C}$. The temperature of $16^{\circ} \mathrm{C}$ was achieved by cooling the sample in an external exposure, $23{ }^{\circ} \mathrm{C}$ was obtained at room temperature, while $60-80{ }^{\circ} \mathrm{C}$ temperature in the sample was achieved by heating the rock at the constructed stand (Fig. 4). The heating element was an infrared lamp imitating solar radiation. The TCi sensor was placed on the opposite side of the rock plate. Due to technical reasons, in the conditions of heating with a lamp, the measurement of thermal parameters was not always possible in the direction perpendicular to the foliation of rock. In other cases, measurements were made for both directions, i.e. perpendicular and parallel to the separation surface.

\section{Results and discussion}

\section{Mineral composition}

Roofing slate samples from Moravian Formation are relatively uniform in macroscopic terms showing a grey colour, a greasy touch and slaty cleavage.

Samples of slates coming from Flysch Carpathians region are more varied. Sample VEG1, representing Vendrynĕ Formation, is grey calcareous clayey siltstone. Sample TRG1, also from Vendrynĕ Formation, is grey calcareous silty claystone. Sample OSTR1 of Hradiště Formation represents black non-calcareous claystone. Sample KUN2 from Veřovice Formation is dark grey non-calcareous shale with trace fossils, and iron oxide stains. All of these flysch samples are of very good shale cleavage.

As it can be noted in Table 2, rocks from Moravian formation have relatively high quartz content (26.42 to $49.11 \%$ ). The proportion between rigid and elastic minerals determines the slate's hardness, with respect to mining, production and finishing of the roof [2]. When taking into account content of rigid minerals, such as quartz and feldspar, and that of elastic minerals-micas, it should be noted that the Moravian formation rocks belong to medium-hard and hard slates. It should be noted also, that slates belonging to this group usually contain some

Table 2 Mineral composition (XRD [mass\%]) of the analysed samples

\begin{tabular}{|c|c|c|c|c|c|c|c|c|c|c|}
\hline Sample & Quartz & K-Feldspar & Albite & Kaolinite & Muscovite & Chlorite & Pyrite & Calcite & Dolomite & Jarosite \\
\hline MOK1 & 28.62 & 2.98 & 20.31 & - & 32.32 & 15.07 & 0.63 & - & - & - \\
\hline MOK2 & 28.70 & 4.18 & 18.23 & - & 31.25 & 16.79 & 0.85 & - & & - \\
\hline ZAL3 & 27.77 & 2.30 & 17.84 & - & 34.92 & 17.17 & - & - & & - \\
\hline LHO4 & 28.36 & 2.62 & 21.01 & - & 30.11 & 15.05 & - & 2.33 & & 0.52 \\
\hline CER5 & 24.26 & - & 18.30 & - & 40.06 & 17.34 & - & 0.04 & & - \\
\hline CER6 & 26.42 & - & 21.90 & - & 32.26 & 19.42 & - & - & - & - \\
\hline OLD7 & 39.16 & 1.21 & 22.14 & - & 22.40 & 15.07 & - & 0.02 & - & - \\
\hline VOD8 & 49.11 & - & 27.03 & - & 13.64 & 10.22 & - & - & - & - \\
\hline VEG1 & 15.72 & - & 2.06 & - & 11.42 & - & 1.01 & 63.04 & 6.75 & - \\
\hline TRG1 & 14.36 & - & 2.58 & - & 9.58 & - & 0.66 & 65.14 & 7.68 & - \\
\hline OSTR1 & 57.87 & - & 4.98 & - & 29.47 & 2.14 & 0.68 & - & 4.86 & - \\
\hline KUN2 & 70.82 & - & 2.15 & 4.44 & 14.20 & 2.74 & 0.44 & - & 5.25 & - \\
\hline
\end{tabular}


Table 3 Thermal parameters of examined slates measured at room temperature

\begin{tabular}{|c|c|c|c|c|c|c|c|c|c|}
\hline \multirow[t]{2}{*}{ Sample } & \multicolumn{2}{|c|}{$\begin{array}{l}\text { Thermal } \\
\text { conductivity } \\
k / \mathrm{W} \mathrm{m}^{-1} \mathrm{~K}^{-1}\end{array}$} & \multirow{2}{*}{$\begin{array}{l}\text { Anisotropy coeffi- } \\
\text { cient of conductivity } \\
k_{\mathrm{II}} / k_{\perp}\end{array}$} & \multicolumn{2}{|c|}{$\begin{array}{l}\text { Effusivity } \\
e / \mathrm{W} \times \mathrm{s}^{0.5} \mathrm{~m}^{-2} \mathrm{~K}^{-1}\end{array}$} & \multirow{2}{*}{$\begin{array}{l}\text { Anisotropy coef- } \\
\text { ficientlof effusivity } \\
e_{\mathrm{II}} e_{\perp}\end{array}$} & \multicolumn{2}{|c|}{$\begin{array}{l}\text { Diffusivity } \\
\alpha / 1 \times 10^{-7} \mathrm{~m}^{2} \mathrm{~s}^{-1}\end{array}$} & \multirow{2}{*}{$\begin{array}{l}\text { Anisotropy coeffi- } \\
\text { cient of diffusivity } \\
\alpha_{\mathrm{II}} \alpha_{\perp}\end{array}$} \\
\hline & $k_{\mathrm{II}}$ & $k_{\perp}$ & & $e_{\mathrm{II}}$ & $e_{\perp}$ & & $\alpha_{\mathrm{II}}$ & $\alpha_{\perp}$ & \\
\hline MOK1 & 3.65 & 1.61 & 2.3 & 2814.6 & 1798.3 & 1.6 & 16.8 & 8.0 & 2.1 \\
\hline MOK2 & 3.92 & 1.52 & 2.6 & 2877.5 & 1724.83 & 1.7 & 18.6 & 7.8 & 2.4 \\
\hline ZAL3 & 3.42 & 1.43 & 2.4 & 2660.4 & 1674.3 & 1.6 & 16.5 & 7.3 & 2.3 \\
\hline LHO4 & 3.70 & 1.79 & 2.1 & 2780.6 & 1866.8 & 1.5 & 17.7 & 9.2 & 1.9 \\
\hline CER5 & 3.61 & 1.52 & 2.4 & 2741.0 & 1725.1 & 1.6 & 17.3 & 7.8 & 2.2 \\
\hline CER6 & 3.58 & 1.65 & 2.2 & 2782.4 & 1762.8 & 1.6 & 16.6 & 8.7 & 1.9 \\
\hline OLD7 & 3.72 & 1.71 & 2.2 & 2775.6 & 1897.2 & 1.5 & 17.9 & 8.1 & 2.2 \\
\hline VOD8 & 3.49 & 1.51 & 2.3 & 2669.5 & 1726.4 & 1.6 & 17.1 & 7.6 & 2.2 \\
\hline VEG1 & 2.86 & 2.65 & 1.1 & 2396.1 & 2295.3 & 1.0 & 14.2 & 1.3 & 1.1 \\
\hline TRG1 & 2.69 & 2.40 & 1.1 & 2319.8 & 2176.1 & 1.1 & 13.4 & 1.2 & 1.1 \\
\hline OSTR1 & 3.02 & 1.99 & 1.5 & 2473.7 & 1968.9 & 1.3 & 14.9 & 1.0 & 1.5 \\
\hline KUN2 & 3.40 & 3.15 & 1.1 & 2650.9 & 2535.1 & 1.1 & 16.4 & 1.5 & 1.1 \\
\hline
\end{tabular}

carbonaceous matter (in form of graphite) which gives dark grey colour to these rocks. This matter, however, could not be detected by XRD measurement.

The rocks coming from Flysch Carpathians region are more differentiated in terms of mineral composition. In case of samples VEG1 and TRG1 the dominant minerals are carbonates (calcite and dolomite_altogether 69.79-72.82\%), whereas in case of samples OSTR1 and KUN2 the most important component is quartz (57.87-70.82\%). In both cases rigid minerals prevail; hence, these rocks are expected to be hard.

\section{Thermal properties}

The used device for thermal conductivity measurement (TCi) is very convenient measuring tool, which was also documented by Cha et al. [15], who used a range of thermal conductivity meters for building materials.

The obtained results of the thermal properties are presented in Table 3 and Fig. 4. Thermal conductivity of the Moravian slates in the direction perpendicular to the bedding $\left(k_{\perp}\right)$ ranges from 1.43 to $1.79 \mathrm{~W} \mathrm{~m}^{-1} \mathrm{~K}^{-1}$. This parameter measured in the direction parallel to the rock bedding $\left(k_{\mathrm{II}}\right)$ is in range of 3.66 to $3.92 \mathrm{~W} \mathrm{~m}^{-1} \mathrm{~K}^{-1}$. In case of samples from Carpathian region $k_{\perp}$ ranges from 1.99 to $3.15 \mathrm{~W} \mathrm{~m}^{-1} \mathrm{~K}^{-1}$, whereas $k_{\mathrm{II}}$ is in range of 2.69 to $3.40 \mathrm{~W} \mathrm{~m}^{-1} \mathrm{~K}^{-1}$.

Roofing slates are described in the literature as rocks of very low thermal and electrical conductivity, and of relatively high resistance to temperature changes. The obtained values of thermal conductivity for the examined rocks are, however, not within the range given for shale rock by Blackwell and Steele [18], i.e. $1.05-1.45 \mathrm{~W} \mathrm{~m}^{-1} \mathrm{~K}^{-1}$. The reason for this discrepancy is probably the relatively high quartz content in the samples tested. When analysing the obtained results, it is visible that the higher values of thermal conductivity correlate with the higher content of quartz in the sample. Unfortunately, the XRD analysis does not provide information on the content of organic matter in rocks, which would additionally facilitate interpretation. The presence of organic matter usually contributes to lowering the thermal conductivity of rocks [19].

The difference between values of $\mathrm{k}_{\mathrm{II}}$ and $\mathrm{k}_{\perp}$ is expressed by anisotropy coefficient $\left(k_{\mathrm{II}} / k_{\perp}\right)$. In most cases of Moravian slates, the anisotropy value is over 2 , which means that $\mathrm{k}_{\mathrm{II}}$ is more than twice the value of $k_{\perp}$. In case of Carpathian shales, this coefficient is significantly lower (mostly 1.1), which means that the slate separation in the second group of rocks is much smaller and has practically no effect on the thermal parameters. The anisotropy coefficient of thermal conductivity for the Moravian slate samples ranges from 2.1 to 2.6 (Table 2, Fig. 5). This is a relatively high value, resulting from the presence of minerals with a foliated (lamellar) habit (muscovite, chlorites) in the studied rocks. However, due to the use of roofing slates, the most important parameter is thermal conductivity (and derivative thermal parameters) measured in a plane perpendicular to the surface of separation.

Effusivity measured along the bedding is between 2319.8 and $2877.5 \mathrm{~W} \mathrm{~s}^{0.5} \mathrm{~m}^{-2} \mathrm{~K}^{-1}$, while in the range of 1674.3-2535.1 W s ${ }^{0.5} \mathrm{~m}^{-2} \mathrm{~K}^{-1}$ in perpendicular direction. Thermal diffusivity values are differentiated for the two regarded rock groups; they are generally higher for Moravian slates. In this group in the direction parallel to the bedding thermal diffusivity values fall between $16.5 \times 10^{-7}$ and $18.6 \times 10^{-7} \mathrm{~m}^{2} \mathrm{~s}^{-1}$ while in perpendicular direction 


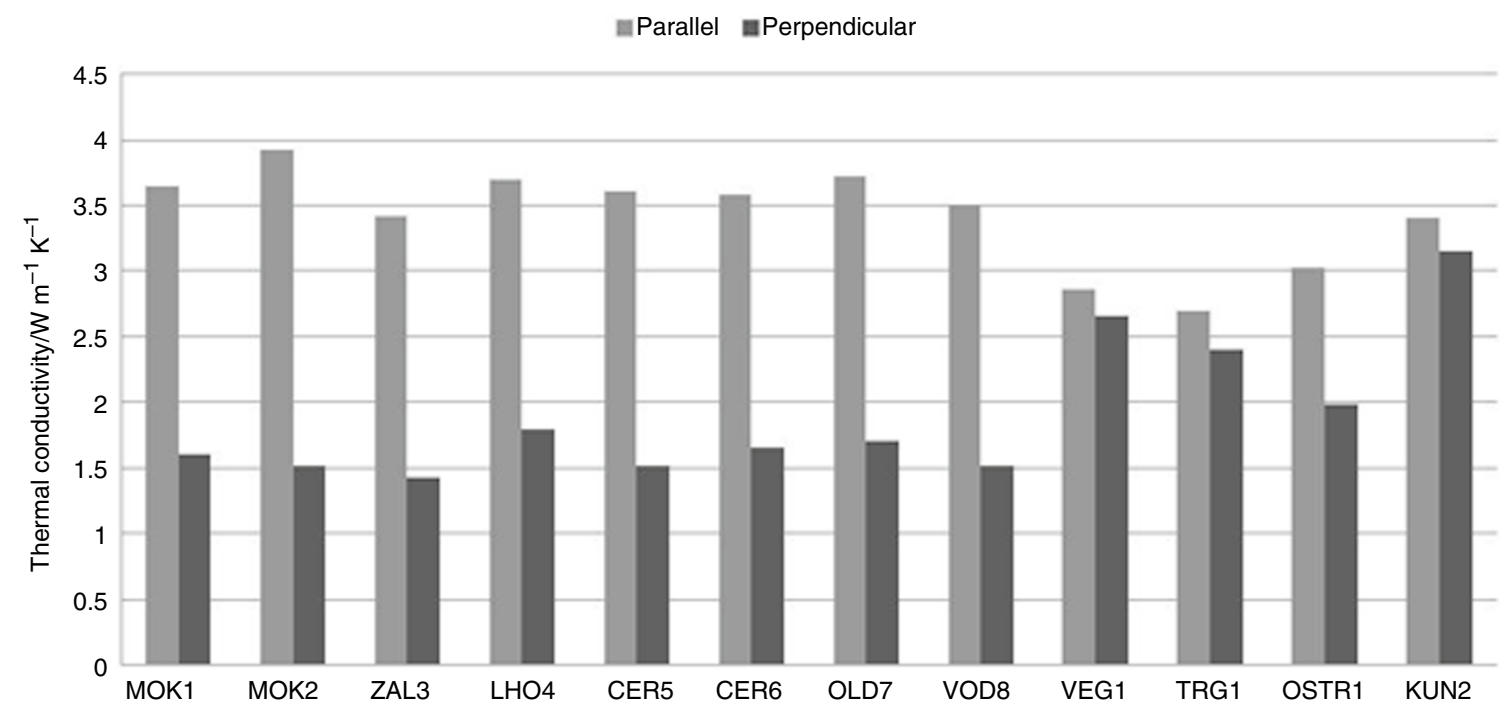

Fig. 5 Average thermal conductivity in the direction parallel and perpendicular to the surface of separation at room temperature

Fig. 6 Dependence of thermal conductivity on temperaturemeasurements for the direction perpendicular to the surface of separation

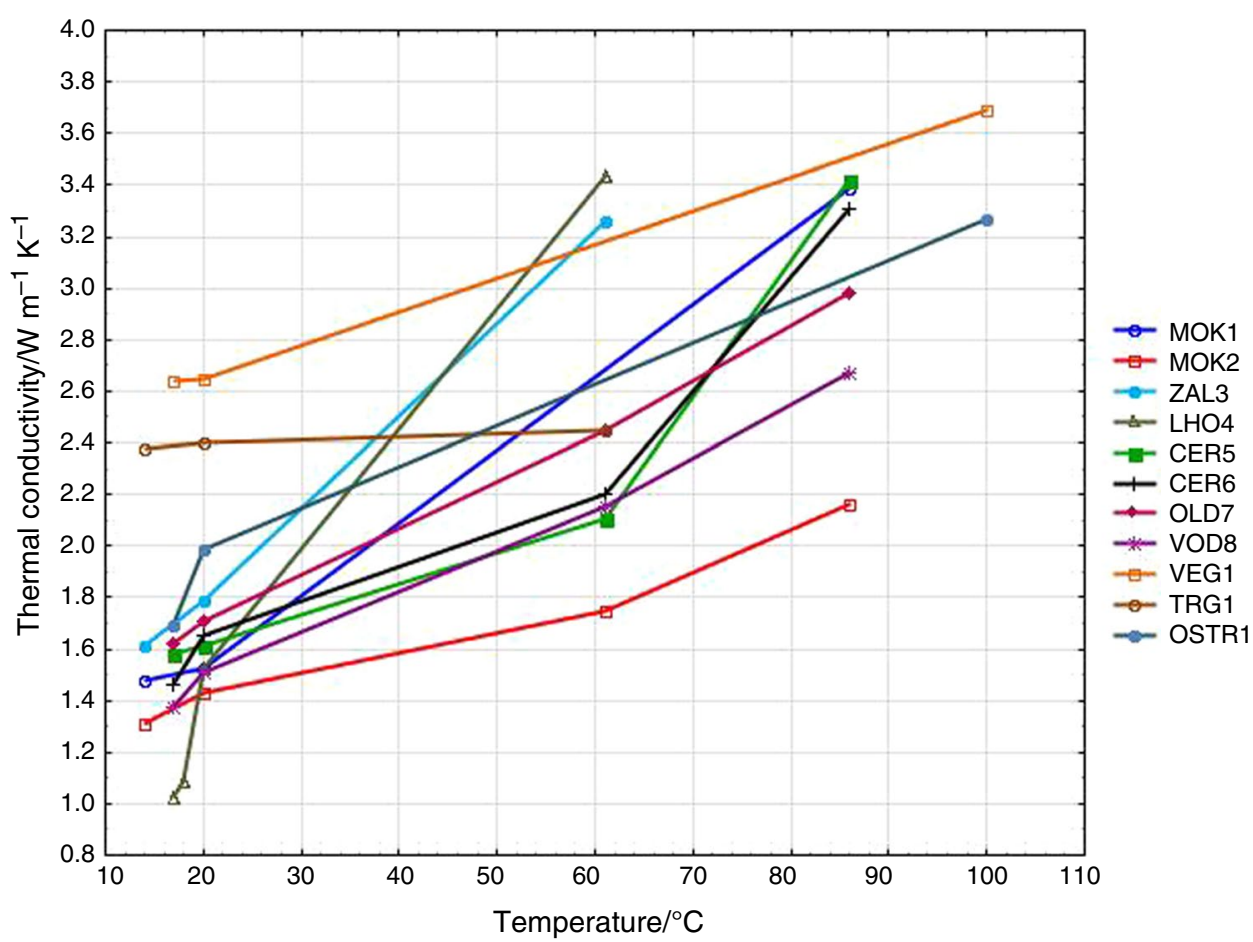

range between $7.3 \times 10^{-7}$ and $9.2 \times 10^{-7} \mathrm{~m}^{2} \mathrm{~s}^{-1}$. In case of Carpathian flysh rocks thermal diffusivity values in direction parallel to the bedding fall between $13.4 \times 10^{-7}$ and $16.4 \times 10^{-7} \mathrm{~m}^{2} \mathrm{~s}^{-1}$, while in perpendicular direction range between $1.0 \times 10^{-7}$ and $1.5 \times 10^{-7} \mathrm{~m}^{2} \mathrm{~s}^{-1}$. The above comparison shows that heat moves more rapidly in direction parallel to bedding, in both groups, which is not surprising phenomenon. Moreover, it is visible that the rock material which reacts quicker to a change in temperature is Moravian slate.
The thermal conductivity values measured for directions perpendicular to the separation surface under variable temperature conditions are presented in Fig. 6. The lowest value was obtained for sample CER5 under temperature $17{ }^{\circ} \mathrm{C}\left(1.03 \mathrm{~W} \mathrm{~m}^{-1} \mathrm{~K}^{-1}\right)$; and the highest for MOK1 and MOK2 under temperature $86{ }^{\circ} \mathrm{C}$ (3.42 and $3.39 \mathrm{~W} \mathrm{~m}^{-1} \mathrm{~K}^{-1}$, respectively), and for sample VEG1 under temperature $100{ }^{\circ} \mathrm{C}\left(3.69 \mathrm{~W} \mathrm{~m}^{-1} \mathrm{~K}^{-1}\right)$.

Generally, the measurements of thermal conductivity at temperatures different from room temperature indicate a 
clear increase in this parameter with the temperature of the sample (Fig. 6). The calculated growth gradient of thermal conductivity ranges from 0.014 to $0.526 \mathrm{~W} \mathrm{~m}^{-1} \mathrm{~K}^{-1}$ per $10{ }^{\circ} \mathrm{C}$.

The strongest growth was recorded for sample LHO4. The stronger increase in the conductivity value along with the temperature is recorded for the Moravian slates, while weaker for the Carpathian flysch rocks. The reason is the texture of these rocks, showing weaker shale separation, due to the genesis of these rocks, as it was already explained in the introductory part of this paper. As it is also noted in the literature, the upward tendency is characteristic for metamorphic rocks, in contrast to sedimentary and igneous rocks [20]. In practice, this means that roofs made of slate have better insulating properties in conditions of lower temperatures, while they are less insulated in conditions of strong sunlight.

\section{Conclusions}

Some thermal parameters of roofing slates were measured on samples from two different formations in the Czech Republic. These were Culm slates of Moravia and Jurassic and Cretaceous slates from the Male Karpaty Mts. The results could be summarized as follows:

1. The mineral composition of the Moravian roofing slates is not very diverse. The basic ingredients include quartz, feldspar, muscovite and chlorite. These rocks are characterized by well-developed rock cleavage, due to the presence of minerals of the sheet type (muscovite, sericite, chlorites). Moravian formation rocks belong to mediumhard and hard slates.

2. Mineral composition of Capathian flysh shales is more differentiated. However, the predominant mineral component is quartz or carbonates (calcite and dolomite), which means that these rocks should be classified as rigid (hard).

3. Thermal conductivity of the Moravian slates in the direction perpendicular to the bedding $\left(k_{\perp}\right)$ ranges from 1.43 to $1.79 \mathrm{~W} \mathrm{~m}^{-1} \mathrm{~K}^{-1}$, while for samples from Carpathian region this parameter ranges from 1.99 to $3.15 \mathrm{~W} \mathrm{~m}^{-1} \mathrm{~K}^{-1}$. These values are higher than reported in the literature for roofing slates.

4. High values of thermal conductivity correlate to higher quartz content in the rocks.

5. The measured thermal parameters (conductivity, effusivity, diffusivity) are strongly depending on the direction of measurement.

6. Thermal conductivity of Moravian roofing slates, measured in direction parallel to the rock bedding is over 2 times higher than measured perpendicular to the bedding planes. Anisotropy coefficient is connected to the presence of sheet-silicate minerals, as micas and chlorites.

7. Anisotropy coefficient for thermal conductivity of Flysh Carpathians shales is significantly lower (over 1), which means that the slate separation in this group of rocks is much smaller and has practically no effect on the thermal parameters.

8. Thermal conductivity of analysed rocks increases along with increase in temperature. The increase in thermal conductivity value is more significant in case of Moravian slates.

In practice, the obtained results indicate that the traditional building material, such as roofing slate, shows better insulation properties at lower temperatures, while in conditions of strong sunlight the temperature conductivity increases. Moreover, in case of roofing slates, which tend to be highly anisotropic, the essential information is the direction of thermal parameters measurement. Slates, due to their specific texture, are characterized by a very high thermal anisotropy coefficient.

Funding This study was funded by the Institute of Applied Geology, Silesian University of Technology. Grant Number: 06/060/BK18/0064.

\section{Compliance with ethical standards}

Conflict of interest The authors declare that they have no conflict of interest.

Informed consent Informed consent was obtained from all individual participants included in the study.

Open Access This article is distributed under the terms of the Creative Commons Attribution 4.0 International License (http://creativeco mmons.org/licenses/by/4.0/), which permits unrestricted use, distribution, and reproduction in any medium, provided you give appropriate credit to the original author(s) and the source, provide a link to the Creative Commons license, and indicate if changes were made.

\section{References}

1. Rapp GR. Archaeomineralogy. Heidelberg: Springer; 2002.

2. Cardenes V, Rubio-Ordoñez A, Wichert J, Cnudde JP, Cnudde V. Petrography of roofing slates. Earth Sci Rev. 2014;138:435-53.

3. Cardenes V, Cnudde V, Cnudde JP. Iberian roofing slate as a Global Heritage Stone Province Resource. Episodes. 2015;38:97-105.

4. Wagner W, Le Bail R, Hacar-Rodriguez MP, Staněk S. European roofing slates. Part 2: geology of selected examples of slate deposits. Z Angew Geol. 1995;41:21-6.

5. Stachowiak A, Cwojdziński S, Ihnatowicz A, Pacuła J, Mrázová Š, Skácelová D, Otava J, Pecina V, Rejchert M, Skácelová Z, Večeřa J. Geostrada sudecka. Przewodnik geologiczno-turystyczny. PIG-PIB ČGS. Warszawa-Praga 2013. 
6. EN 12326-1:2014. Slate and stone for discontinuous roofing and external cladding - Part 1: Specifications for slate and carbonate slate.

7. Cardenes V, Cnudde JP, Wichert J, Large D, López-Mungira A, Cnudde V. Roofing slate standards: a critical review. Constr Build Mat. 2016;115:93-104.

8. Wagner W. Grundlagen für die Prüfung von Dach - und Wandschiefern. Z dt Ges Geowiss. 2007;158(4):785-805.

9. Clauser C, Huenges E. Rock physics \& phase relations. A handbook of physical constants. Thermal conductivity of rocks and minerals. Am Geophys Union. 2013;3:105-26.

10. Chmura K. Przewodność cieplna skał i węgli górnośląskiego karbonu. Gliwice: Zesz Naukowe PŚ; 1968.

11. Plewa S. Wyniki badań petrofizycznych własności skał. PAN Kraków: Pr Geol Komis Nauk Geol; 1977.

12. Busby J. Thermal conductivity and diffusivity estimations for shallow geothermal systems. Q J Eng Geol Hydrogeol. 2016;49:138-46.

13. Luo J, Jia J, Zhao H, Zhu Y, Guo Q, Cheng C. Determination of the thermal conductivity of sandstones from laboratory to field scale. Environ Earth Sci. 2016;75(16):1-9.

14. Di Sipio E, Chiesa S, Destro E, Galgaro A, Giaretta A, Gola G et al. Rock thermal conductivity as key parameter for geothermal numerical models Energy Procedia. 2013; 87-94.
15. Cha J, Seo J, Kim S. Building materials thermal conductivity measurement and correlation with heat flow meter, laser flash analysis and TCi. J Therm Anal Calorim. 2012;109:295-300.

16. Gustafsson SE. Transient plane source techniques for thermal conductivity and thermal diffusivity measurements of solid materials. Rev Sci Instrum. 1991;62:797-804.

17. Harris A, Kazachenko S, Bateman R, Nickerson J, Emanuel M. Measuring the thermal conductivity of heat transfer fluids via the modified transient plane source (MTPS). J Therm Anal Calorim. 2014;116:1309-14.

18. Blackwell D, Steele J. Heat flow and geothermal potential of Kansas. Biul Kans Geol Surv. 1989;226:267-95.

19. Labus M, Labus K. Thermal conductivity and diffusivity of fine-grained sedimentary rocks. J Therm Anal Calorim. 2018;132:1669-76.

20. Plewa M, Plewa S. Petrofizyka. Warszawa: Wyd Geol; 1992.

Publisher's Note Springer Nature remains neutral with regard to jurisdictional claims in published maps and institutional affiliations. 